\title{
RESEARCH
}

Open Access

\section{Effects of simulated acid rain on soil respiration and its component in a mixed coniferous-broadleaved forest of the three gorges reservoir area in Southwest China}

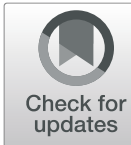

Yifan $\mathrm{Li}^{1,2}$, Yunqi Wang ${ }^{1,2^{*}}$, Yujie Wang ${ }^{1,2}$ and Bin Wang ${ }^{1,2}$

\begin{abstract}
Background: Soil respiration in forest ecosystems is an important part of the forest carbon (C) cycle. Studying the variation patterns of soil respiration under acid rain conditions is critically important for understanding forest $C$ balance and performing rational forest management and operations.

Methods: A split-plot design field experiment was performed in a mixed coniferous-broadleaved forest in the Three Gorges Reservoir Area of Jinyun Mountain, Chongqing from January 2016-January 2018. There were 4 main blocks; each was split into untrenched (UT) and trenched (T) treatments. Treatments with four gradient pH levels of 4.5 (control), 4.0, 3.25 and 2.5 were randomly assigned to the untrenched and trenched treatments. The soil $\mathrm{CO}_{2}$ fluxes, soil temperature, and soil moisture content were evaluated under simulated acid rain. Additionally, the effects of soil properties (soil pH, organic C, C:N ratio, microbial biomass, and enzyme activity) on soil respiration were analysed.

Results: The soil $\mathrm{CO}_{2}$ fluxes exhibited seasonal variation trends. The annual mean soil respiration rates of the UTCK (control), UT4.0, UT3.25, and UT2.5 treatments in untrenched plots were 1.91, 1.91, 1.77, and $1.74 \mu \mathrm{mol} \cdot \mathrm{m}^{-2} \cdot \mathrm{s}^{-1}$ in 2016 and $1.91,1.81,1.55$ and $1.37 \mu \mathrm{mol} \cdot \mathrm{m}^{-2} \cdot \mathrm{s}^{-1}$ in 2017 , respectively. The annual mean heterotrophic respiration rates of the TCK (control), T4.0, T3.25, and T2.5 treatments in the trenched plots were 1.39, 1.32, 1.19 and $1.14 \mu \mathrm{mol} \cdot \mathrm{m}^{-2} \cdot \mathrm{s}^{-1}$ in 2016 and $1.28,1.18,1.02$ and $0.83 \mu \mathrm{mol} \cdot \mathrm{m}^{-2} \cdot \mathrm{s}^{-1}$ in 2017 , respectively. Acid rain had a significant cumulative effect on soil respiration and heterotrophic respiration $(P<0.01)$. In 2016 , soil respiration was similar in the UTCK versus the UT4.0 treatment but significantly inhibited under higher acidity. In 2017, soil respiration and heterotrophic respiration were significantly decreased by simulated acid rain. The treatments increased the temperature sensitivity of soil respiration but did not significantly affect the soil temperature or moisture content $(P>0.05)$; moreover, they significantly increased the soil organic C content and C:N ratio, lowered the hydrolysable $\mathrm{N}$ and total $\mathrm{P}$ concentrations, and lowered the soil pH and fine root biomass at a later experimental stage. Urease and sucrase activities were significantly reduced in the higher-acidity treatments. Soil respiration rate was significantly positively correlated with the soil pH, fine root biomass, and urease and sucrase activity and significantly negatively correlated with the soil organic C and C:N ratio.

\footnotetext{
* Correspondence: wangyunqi@bjfu.edu.cn

${ }^{1}$ School of Soil and Water Conservation, Beijing Forestry University, Beijing 100083, China

${ }^{2}$ Chongqing Jinyun Forest Ecological Station, School of Soil and Water Conservation, Beijing Forestry University, Beijing 100083, China
} 
(Continued from previous page)

Conclusions: Acid rain had a significant cumulative and inhibitory effect on soil respiration and heterotrophic respiration, while soil temperature and moisture had a limited effect on soil respiration under simulated acid rain. The variation in soil properties (e.g., soil organic C, C:N ratio, and fine root biomass) caused by acid rain inhibited the microbial utilization of substrates, which was the main cause of the respiration differences.

Keywords: Simulated acid rain, Soil respiration, $Q_{10}, C: N$ ratio, Enzyme activity

\section{Introduction}

In the context of global climate change, studying the carbon $(\mathrm{C})$ cycle and budget in terrestrial ecosystems has long been a research priority worldwide (Hashimoto et al. 2015). Soil respiration in forest ecosystems constitutes an important part of the forest $C$ cycle (Wei et al. 2010). Acid rain is a global problem, and China is one of the most polluted countries after Europe and North America. This problem is particularly prominent in southern China because the mean $\mathrm{pH}$ of rainfall has often been lower than 4.6 in recent years, even dropping to 3.6 in extreme cases (Huang et al. 2010; Zhang et al. 2011). Most of the ecosystems in this region have experienced changes in ecosystem stability and biogeochemical cycles after acid rain increase (Busch et al. 2001). In forest ecosystems, acid rain can reduce soil acidity, destroy the nutrient cycling process by leaching, release salt-based cations and toxic metals in soil, and cause various effects on soil chemical properties and nutrients (Bowden et al. 2004; Ling et al. 2010). On the one side, acid rain can interfere with the decomposition of organic matter in soil (such as ammoniation and nitrification), destroy nitrogen fixation process, and affect nutrients from plant leaves and roots (Turner and Tingey 1990; Meldahll et al. 1990; Aber et al. 1998). On the other hand, $\mathrm{H}^{+}$ions in acid rain can displace cations from the binding sites of them (e.g., $\mathrm{K}^{+}, \mathrm{Na}^{+}, \mathrm{Ca}^{2+}$, and $\mathrm{Mg}^{2+}$ ), which will not be used as nutrients by plants (Zhang et al. 2007). Toxic ions such as $\mathrm{Al}^{3+}$ can also be displaced in acid rain, resulting in high concentrations of toxic ions in soil solutions, which may cause damage to roots and microbial communities (Kuperman 1996).

Acid rain can affect the plant root status and litter properties, soil microbial community structure and function, and the soil enzyme activities involved in the $\mathrm{C}$ and $\mathrm{N}$ cycles and transformation processes (Lv et al. 2014; Liang et al. 2016). Forest soil respiration may change due to factors such as soil microbes, roots, litter and climate (Ouyang et al. 2008). Thus far, inconsistent results have been obtained from studies that have investigated the effects of acid rain on forest soil respiration. For instance, Zhang et al. (2011) conducted a study from 2009 to 2010 and showed that the soil respiration rate was inhibited by high-intensity acid rain. Liang et al. (2016) found that under acid rain treatment, soil respiration decreased slightly in the first year followed by a significant decrease in the second year. However, Chen et al. (2015) found no significant differences in soil respiration between different simulated acid rain treatments in a mixed coniferous-broadleaved forest. Few studies have investigated the effects of acid rain on forest soil respiration under natural field conditions, and long-term field simulation experiments are currently scarce; thus, whether regional and temporal differences occur is poorly understood. The potential effects and mechanisms of acid rain on soil respiration and its components might vary with the control factors and biological processes of different terrestrial ecosystems. Autotrophic (root) and heterotrophic (microbial and animal) respiration, which are aspects of soil respiration, occur in different ways and have varying feedback on their influencing factors; thus, their responses to acid rain will vary (Wei et al. 2010). It is of great significance to study the variation patterns of soil respiration under acid rain to provide a theoretical reference for rational forest management and operation under acid rain conditions. The accurate identification of different components of soil respiration has always been a difficult and popular topic in the study of underground biology and carbon cycle. Regarding the difference of response of autotrophic respiration and heterotrophic respiration to acid rain, Chen et al. (2015) considered that simulated acid rain increased the proportion of heterotrophic respiration in soil respiration and decreased the proportion of autotrophic respiration. At present, information regarding soil respiration components, particularly their response to acid rain in these forests, is poorly known.

In China, most of the land covered by primary forests has been degraded by human activities. When evergreen monsoon rainforests are destroyed, mixed coniferousbroadleaved forests often occur, and they occupy a significant area of southern China (Brown et al. 1995). However, few studies have been conducted on the soil respiration components and their response to acid rain in these forests (Mo et al. 2007). The city of Chongqing in the Three Gorges Reservoir Area is a typical acid rain area in southern China. Due to industrial development and increasing numbers of motor vehicles, acid rain is converted from a sulphuric acid type to a sulphuric acid-nitric acid mixed type in Chongqing (Guo et al. 2015). Although rainfall pollution has been mitigated in 
recent years through emissions reduction control policies, the acid rain situation is still serious, and further analysis is needed to elucidate the effects of rainfall acidification (Guo 2016).

The objectives of this study were to monitor variation in soil respiration and soil properties and explore the mechanisms underlying the response of soil respiration to acid rain through two-year simulated acid rain experiments in a mixed coniferous-broadleaved forest in Jinyun Mountain, Chongqing. We explored three important questions to help predict how acid rain affects the soil $\mathrm{C}$ balance in forest ecosystems: (1) Does acid rain affect soil respiration and its components in the mixed coniferous-broadleaved forest? (2) How does acid rain affect soil properties, and do variations in soil properties contribute to the variation in soil respiration? (3) How do soil biotic and abiotic factors drive soil respiration under different simulated acid rain treatments?

\section{Study methods \\ Study area description}

The study area is located in the Jinyun Mountain area of Chongqing $\left(106^{\circ} 17^{\prime}-106^{\circ} 24^{\prime}\right.$ E, $\left.29^{\circ} 41^{\prime}-29^{\circ} 52^{\prime} \mathrm{N}\right)$, and it is part of the Three Gorges Reservoir Area with an altitude of $170-950 \mathrm{~m}$. The study area has a typical subtropical monsoon humid climate with an annual mean rainfall of $1611.8 \mathrm{~mm}$ and a mean relative moisture content of $87 \%$. The rainfall during the rainy season (April-September) accounts for $77.2 \%$ of the total annual rainfall. The annual mean temperature is $13.6^{\circ} \mathrm{C}$, and the annual mean evaporation is $777.1 \mathrm{~mm}$. Little rainfall with high evaporation occurs from the end of July to the middle of August each year, thus constituting the drought period. The soil type in the study area is yellow soil with a pH between 3.5 and 4.5; this is an acidic soil with weak anti-erosion ability. The vegetation coverage reaches up to $96.6 \%$. There are four forest types in the Jinyun Mountain area of Chongqing: evergreen broadleaved forest, mixed coniferous-broadleaved forest, coniferous forest and bamboo forest. Our study site is located in the mixed coniferous-broadleaved forest (Table 1). The area of mixed coniferousbroadleaved forest occupies $55.7 \%$ of the total forest area ( $\mathrm{Li}$ 2009). This forest area includes multiple representative ecosystems that include a species gene pool of typical ecological complexes in the Jinyun Mountain area, which can reflect the natural background of forests in this area.

\section{Experimental design and management}

Field experiments was assigned in a split-plot design in the mixed coniferous-broadleaved forests. There were 4 main blocks (duplicates), each of which was split into untrenched (UT) and trenched (T) treatments. The 4 acid rain treatments were randomly assigned in each of the untrenched and trenched treatments: control $(\mathrm{pH}$ 4.5), low-intensity acid ( $\mathrm{pH} 4.0)$, medium-intensity acid (pH 3.25), high-intensity acid ( $\mathrm{pH} 2.5)$, designated UTCK, UT4.0, UT3.25, and UT2.5 into untrenched plots and TCK, T4.0, T3.25, and T2.5 into trenched plots. There were a total of 32 micro-plots assigned in field, with each micro-plot area measuring $2 \mathrm{~m} \times 2 \mathrm{~m}$. The distance between the two micro-plots was more than $4 \mathrm{~m}$ to prevent interference caused by mutual influence. Soil respiration $\left(R_{\mathrm{s}}\right)$ and heterotrophic respiration $\left(R_{\mathrm{h}}\right)$ were distinguished by the trench method, excluding roots; this approach has precedent in the soil respiration literature but holds some drawbacks such as higher soil moisture on trenched plots, additional sources of $\mathrm{CO}_{2}$ from decaying dead roots, and autotrophic respiration being assigned to heterotrophic respiration because roots are existed below a depth of $40 \mathrm{~cm}$. The interference was minimized by carefully digging trenches ( 40 $\mathrm{cm}$ ) around trenched plots (when the depth of trenching was more than $40 \mathrm{~cm}$, soil parent material composed of rock weathering debris emerged, and the root seldom existed), and then, the roots inside and outside the plots were separated by inserting a PVC plate. The trenched plots were vacant for 6 months, which allowed the roots in the plots to decompose completely and prevented $\mathrm{CO}_{2}$ from causing higher $R_{\mathrm{h}}$. The untrenched plots removed only the plants inside the PVC collars. The flux observed in the trenched plots represented the heterotrophic component $\left(R_{\mathrm{h}}\right)$ in soil respiration, and soil respiration $\left(R_{\mathrm{s}}\right)$ was observed in the untrenched plots. The $\mathrm{CK}$ group was set to the annual mean rainfall $\mathrm{pH}$ of 4.5 in a natural state, while the T3.25 group was set to the lowest rainfall $\mathrm{pH}$ value. Given that the rainfall $\mathrm{pH}$

Table 1 Basic characteristics of the forest stand in the sample plots

\begin{tabular}{|c|c|c|c|c|c|c|c|c|}
\hline \multicolumn{3}{|c|}{ Site factor } & \multicolumn{5}{|c|}{ Forest stand characteristics } & \multirow[t]{2}{*}{ Major tree species } \\
\hline $\begin{array}{l}\text { Altitude } \\
\text { (m) }\end{array}$ & $\begin{array}{l}\text { Slope } \\
\left({ }^{\circ}\right)\end{array}$ & Aspect & Origin & $\begin{array}{l}\text { Canopy } \\
\text { density }\end{array}$ & $\begin{array}{l}\text { Stand density } \\
\left(\text { trees } h \mathrm{ha}^{-1} \text { ) }\right.\end{array}$ & $\begin{array}{l}\text { Mean diameter } \\
\text { at breast } \\
\text { height }(\mathrm{cm})\end{array}$ & $\begin{array}{l}\text { Mean tree } \\
\text { height }(m)\end{array}$ & \\
\hline 868.4 & 12 & Northwest & Natural & 0.88 & 2185 & 10.22 & 12.74 & $\begin{array}{l}\text { Gordonia acuminata, Neolitsea aurata, Adinandra } \\
\text { bockiana, Symplocos setchuenensis, Pinus massoniana, } \\
\text { and Cunninghamia lanceolata }\end{array}$ \\
\hline
\end{tabular}


might be lower under extreme conditions, we also established the T2.5 group, and finally, the T4.0 group was added to form a gradient (Liang et al. 2016; Guo et al. 2016). To reflect the trend in the molar ratio of S:N in rainfall, we prepared a mother liquor of acid rain with a $\mathrm{pH}$ of 1.0 using $\mathrm{H}_{2} \mathrm{SO}_{4}$ and $\mathrm{HNO}_{3}$ at a 5:1 ratio (Tang et al. 2015). Then, the mother liquor of acid rain was mixed with deionized water to obtain $\mathrm{pH}$ values of 4.5 , 4.0, 3.25, and 2.5. The experiment lasted from January 2016 to January 2018, and acid rain was applied once every 2 weeks during the experimental period. Acid rain was sprayed back and forth uniformly and manually with a spray bottle. All quadrats were sprayed within a day. For each application, $8 \mathrm{~L}$ of acid rain per quadrat was sprayed, equivalent to $2 \mathrm{~mm}$ of rainfall. The annual input of $\mathrm{H}^{+}$load for the natural-state quadrats was 0.4292 $\mathrm{kmol} \cdot \mathrm{ha}^{-1}$, and the $\mathrm{H}^{+}$load added to the T2.5, T3.25, T4.0, and CK treatments were 4, 0.62, 0.11, and 0.04 times higher than that of natural rainfall, respectively (Liang et al. 2016; Guo et al. 2016).

\section{Determination of soil respiration, temperature, and moisture content}

A soil ring (outer diameter, $20 \mathrm{~cm}$; inner diameter, $19.5 \mathrm{~cm}$, and height, $12 \mathrm{~cm}$ ) was inserted into the soil at the centre of each quadrat; a length of $2.5 \mathrm{~cm}$ was exposed above the ground, and all living organisms within the ring were removed. The soil respiration rate under natural conditions was measured using a LI-8100 open-circuit soil respiration measurement system (LI-COR, Lincoln, NE, USA). Measurements were performed twice at 09:00-11:00 over two consecutive days selected within the first, middle, and last 10 days of each month during the experimental period, and the mean value was taken as the mean daily soil respiration rate. A previous study showed that the measured values at this time interval were close to the daily mean values of soil respiration ( $\mathrm{Yu}$ 2015; Jian et al. 2018). There were four replicates for the four quadrats per treatment. Soil respiration was measured 2 days following each application of acid rain to avoid a spike in soil respiration due to the spraying. Soil temperature and moisture content (volumetric fraction) were measured at a depth of 5 $\mathrm{cm}$ using an Em50G data logger (LI-COR, Lincoln, NE, USA) equipped with a 5TM soil moisture and temperature sensor. One sensor was placed in each quadrat.

\section{Sample collection and analysis}

In April 2016, October 2016, April 2017, and October 2017, the soil samples $(0-10 \mathrm{~cm})$ were taken from each quadrat with a cutting ring using a five-point method, placed into a plastic bag, mixed evenly, and then brought back to the laboratory. Four replicates per treatment were collected each time. The collected soil samples were dried, milled and sifted to determine the soil $\mathrm{pH}$ value. The glass electrode method was used (soil-water ratio was 1:2.5). When collecting the soil samples, topsoil $(0-10 \mathrm{~cm})$ cores were taken from each quadrat with a soil auger $(10 \mathrm{~cm} \times 7 \mathrm{~cm})$ using a five-point method. Five cores per quadrat were combined, placed into a plastic bag, and then brought back to the laboratory. The soil cores were sieved and rinsed with distilled water. The root samples were oven-dried to a constant weight at $65^{\circ} \mathrm{C}$. The fine roots were examined with a Vernier calliper $(d<10 \mathrm{~mm})$, weighed, and recorded. Four replicates per treatment were taken each time.

In addition, a portion of the fresh soil samples collected in October 2017 was immediately used to determine the soil microbial biomass $\mathrm{C}$, microbial biomass $\mathrm{N}$, and enzyme activity. The remainder was air-dried, ground, and sieved before soil chemical analysis. The organic $\mathrm{C}$ content was determined by oxidation with dichromate plus titration with ammonium ferrous sulphate (Liu 1996). The hydrolysable $\mathrm{N}$ concentration was determined by boric acid absorption-hydrochloric acid titration (Bao 2000), and the total $\mathrm{N}$ concentration was determined using the Kjeldahl method (Bao 2000). The available P concentration was determined by extraction with sulphuric acid and hydrochloric acid, while the total P concentration was determined after the soil was digested with sulphuric acid and perchloric acid (Bao 2000). The soil microbial biomass $\mathrm{C}$ and $\mathrm{N}$ were determined using a chloroform fumigation-extraction method ( $\mathrm{Lu}$ 1999). The activity levels of the enzymes (acid phosphatase (Kandeler et al. 1999), urease (Nannipieri et al. 1980), and sucrase (Gopal et al. 2007; Gu et al. 2009) were determined by spectrophotometry. Toluene was used as a biological activity inhibitor. The measurement results of the soils were calculated on a dry-weight basis.

\section{Data analysis}

A repeated-measures analysis of variance (ANOVA) with a split-plot design was used to test the effects of trenching, simulated acid rain, and their interactions on the soil $\mathrm{CO}_{2}$ flux, annual mean soil respiration rate, annual cumulative soil respiration, soil temperature, soil moisture, soil $\mathrm{pH}$, and fine root biomass $(P<0.05)$ followed by the least significant difference test for multiple comparisons. A one-way ANOVA was performed to determine significant differences in soil properties such as soil $\mathrm{pH}$, organic $\mathrm{C}$, and $\mathrm{C}: \mathrm{N}$ ratio $(P<0.05)$ followed by the least significant difference test for multiple comparisons. The linear model was used to analyse the positive proportional function relationship between heterotrophic respiration and total soil respiration. The 
exponential function model was used to fit the relationship between soil temperature and soil respiration, the quadratic function model was used to fit the relationship between soil moisture and soil respiration, and a twofactor model with an added interaction factor (soil temperature $\times$ soil moisture) was used to fit the relationship of soil temperature, soil moisture, and soil respiration. Pearson's correlation coefficient was calculated to analyse the correlations between soil properties such as soil $\mathrm{pH}$, organic $\mathrm{C}$, and $\mathrm{C}: \mathrm{N}$ ratio versus soil respiration. Because soil respiration was not measured daily, the measured soil respiration and the $5-\mathrm{cm}$ soil temperature and moisture content were used to establish the fitting equation and calculate the daily soil respiration rate. Daily $\mathrm{CO}_{2}$ emissions were aggregated to obtain cumulative soil respiration. All calculations, analyses, and graphic drawings were performed using Excel 2016, SPSS 19.0, and OriginPro 9.0 software.

\section{Results \\ Variation in soil respiration, soil temperature, and soil moisture content under different acid rain intensities}

The soil temperature showed a similar seasonal variation trend across the different simulated acid rain treatments, and it was highest in summer and lowest in winter. From 2016 to 2017, the soil temperatures of the UTCK, UT4.0, UT3.25, and UT2.5 treatments fell in the ranges of 4.7824.97, 4.87-25.08, 4.66-24.68, and 4.64-24.95 ${ }^{\circ} \mathrm{C}$, and those of the TCK, T4.0, T3.25, and T2.5 treatments fell in the ranges of 5.62-24.51, 5.48-24.90, 5.50-24.98 and 5.38$24.43^{\circ} \mathrm{C}$, respectively (Fig. $1 \mathrm{~A}$ and $\mathrm{C}$ ). The soil moisture content fluctuated strongly due to rainfall, with the lowest value of the year in August and September. From 2016 to 2017, the soil moisture content of the UTCK, UT4.0, UT3.25 and UT2.5 treatments ranged from 14.05\%$32.45 \%, \quad 14.23 \%-32.84 \%, \quad 13.88 \%-33.02 \%$ and $13.96 \%-$ $33.21 \%$, and that of the TCK, T4.0, T3.25, and T2.5 treatments ranged from $14.05 \%-29.60 \%, 14.23 \%-30.33 \%$, $13.76 \%-29.88 \%$ and $13.93 \%-29.53 \%$, respectively (Fig. 1B and $\mathrm{D}$ ). The two-factor repeated-measures ANOVA of the soil temperature and soil moisture content showed that both parameters were significantly affected by time (respiration component $)(P<0.01)$, while no significant effects were observed for the different intensities in simulated acid rain $(P>0.05)$ and their interactions with time $(P>0.05$; Table 2).

$R_{\mathrm{s}}$ and $R_{\mathrm{h}}$ showed a unimodal trend across different simulated acid rain treatments during 2016-2017, with the peak values recorded in August and September and the lowest values in January and February (Fig. 1E and F). This behaviour is generally consistent with the trend in soil temperature but markedly different from the trend in soil moisture content. The annual mean soil respiration rates of the UTCK, UT4.0, UT3.25, and
UT2.5 treatments were 1.91, 1.91, 1.77, and $1.74 \mu \mathrm{mol} \cdot \mathrm{m}^{-2} \cdot \mathrm{s}^{-1}$ in 2016 and $1.91,1.81,1.55$, and $1.37 \mu \mathrm{mol} \cdot \mathrm{m}^{-2} \cdot \mathrm{s}^{-1}$ in 2017 , respectively. The annual mean heterotrophic respiration rates of the TCK, T4.0, T3.25, and T2.5 treatments were 1.39, 1.32, 1.19, and $1.14 \mu \mathrm{mol} \cdot \mathrm{m}^{-2} \cdot \mathrm{s}^{-1}$ in 2016 and $1.28,1.18,1.02$, and $0.83 \mu \mathrm{mol} \cdot \mathrm{m}^{-2} \cdot \mathrm{s}^{-1}$ in 2017 , respectively. The two-factor (trenching and SAR) ANOVA showed that the respiration rate was significantly affected by trenching $(P<$ $0.01)$, different simulated acid rain treatments $(P<$ $0.01)$, and their interactions $(P<0.05$; Table 2$)$. The inhibition effects of simulated acid rain on soil $\mathrm{CO}_{2}$ emission was contingent on the specific respiration components. The repeated-measures ANOVA showed that the effects of simulated acid rain on soil $\mathrm{CO}_{2}$ emission, annual mean soil respiration rate, and annual cumulative soil respiration was significantly affected by time $(P<0.01$; Table 2$)$. Compared with the control, the mean soil respiration of 2016 in the UT3.25 and UT2.5 treatments decreased significantly by $6.92 \%$ and $8.67 \%$, and the cumulative soil respiration of 2016 decreased significantly by $12.21 \%$ and $13.71 \%$, respectively (Fig. $2 \mathrm{~A}$ and $\mathrm{B})$. However, there was no significant difference between the UT4.0 and UTCK treatments $(P>0.05)$, and there was no significant difference between UT3.25 and UT2.5 treatments $(P>0.05)$. The mean soil respiration of 2017 in the UT2.5, UT3.25, and UT2.5 treatments decreased significantly by $5.17 \%, 18.90 \%$, and $28.35 \%$, respectively, and the cumulative soil respiration of 2017 decreased significantly by $21.77 \%, 12.22 \%$, and $17.29 \%$. Compared with the control, the mean heterotrophic respiration of 2016 in the T4.0, T3.25, and T2.5 treatments decreased significantly by $5.12 \%, 14.50 \%$, and $17.94 \%$, respectively, and the means of 2017 decreased significantly by $7.86 \%, 20.22 \%$, and $35.51 \%$ (Fig. 2C). The cumulative heterotrophic respiration of 2016 in the T4.0, T3.25, and T2.5 treatments decreased significantly by $7.99 \%, 15.15 \%$, and $21.91 \%$, respectively, and the cumulative soil respiration of 2017 decreased significantly by $9.22 \%, 16.21 \%$, and $28.68 \%$ (Fig. 2D). Significant differences were observed among different simulated acid rain in the trenched treatment in 2016 and $2017(P<$ 0.01).

As shown in Fig. 3, the regression analysis showed that there was a positive correlation between soil respiration under the trenched treatment and heterotrophic respiration under the untrenched treatment $(P<0.01)$. The $R^{2}$ of each treatment was above 0.8 . The ratio of heterotrophic respiration to soil respiration was $70.66 \%, 68.66 \%, 66.40 \%$, and $62.76 \%$ under the control, $\mathrm{pH} 4.0, \mathrm{pH} 3.25$ and $\mathrm{pH} 2.5$ treatments, respectively, indicating that the proportion of heterotrophic respiration decreased gradually with increasing acid rain acidity. 


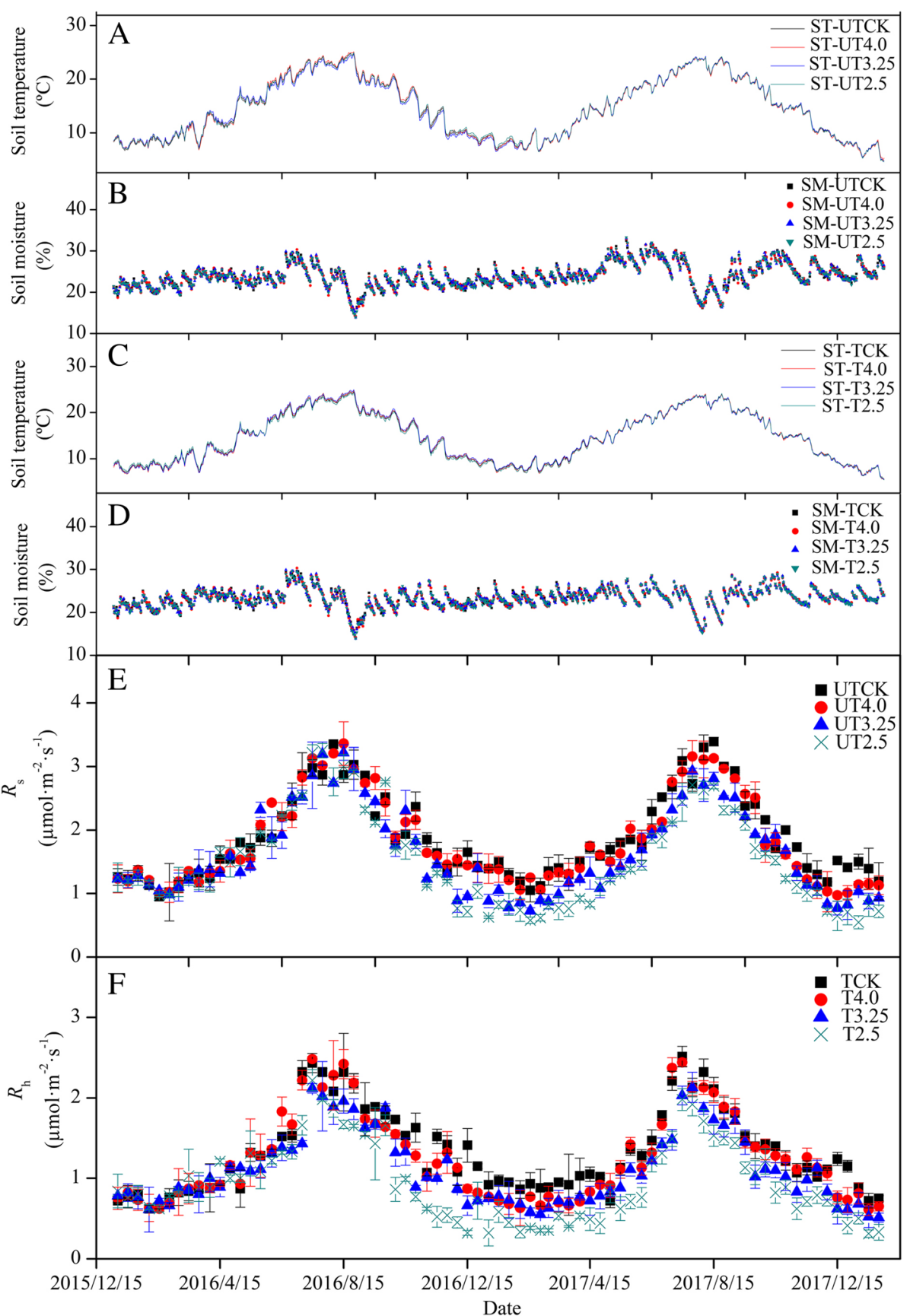

Fig. 1 Dynamic variation in 5-cm soil temperature ( $A$ and C), 5-cm soil water content ( $B$ and $D$ ), soil respiration (E), and heterotrophic respiration (F) under different treatments. Vertical bars represent standard errors $(n=4)$. ST indicates the $5-\mathrm{cm}$ soil temperature. SM indicates the $5-\mathrm{cm}$ soil moisture content. UTCK, UT4.0, UT3.25, and UT2.5 indicate control, $\mathrm{pH} 4.0, \mathrm{pH} 3.25$, and pH 2.5 simulated acid rain in the untrenched plots, respectively; TCK, T4.0, T3.25, and T2.5 indicate the control, $\mathrm{pH} 4.0, \mathrm{pH} 3.25$, and $\mathrm{pH} 2.5$ simulated acid rain in the trenched plots, respectively

Variation in soil properties under different acid rain intensities

Soil $\mathrm{pH}$, fine root biomass, microbial biomass, and enzyme activity

All soil samples collected from the different treatments were acidic. In the early stage of the experiment (April 2016), there was no significant difference in soil $\mathrm{pH}$ between the trenched treatment and the untrenched treatment $(P>0.05)$, and then, differences gradually emerged. In the samples collected in October 2017, there were decreases of $1.79 \%, 2.55 \%$, and $5.10 \%$ in the UT4.0, UT3.25, and UT2.5 treatments compared with the CK, respectively, while there were decreases of $2.59 \%, 5.18 \%$, and $9.07 \%$ in 
Table 2 Repeated-measures ANOVA for the split-plot experiments. SS: sum of squares; MS: mean of squares

\begin{tabular}{|c|c|c|c|c|c|c|}
\hline Variable & Source & SS & df & MS & F-ratio & $P$ \\
\hline \multirow[t]{7}{*}{ 5-cm soil temperature } & RC & 0.04 & 1.00 & 0.04 & 0.65 & 0.428 \\
\hline & SAR & 0.42 & 3.00 & 0.14 & 2.04 & 0.135 \\
\hline & $\mathrm{RC} \times \mathrm{SAR}$ & 0.31 & 3.00 & 0.11 & 1.54 & 0.231 \\
\hline & Times & $20,715.41$ & 23.00 & 900.67 & $17,913.89$ & $<0.001$ \\
\hline & Times $\times$ SAR & 2.05 & 69.00 & 0.03 & 0.59 & 0.996 \\
\hline & Times $\times R C \times S A R$ & 3.23 & 69.00 & 0.05 & 0.93 & 0.635 \\
\hline & Error & 27.75 & 552.00 & 0.05 & & \\
\hline \multirow[t]{7}{*}{ 5-cm soil water content } & $\mathrm{RC}$ & 18.31 & 1.00 & 18.31 & 57.55 & $<0.001$ \\
\hline & SAR & 1.97 & 3.00 & 0.66 & 2.07 & 0.131 \\
\hline & $\mathrm{RC} \times \mathrm{SAR}$ & 0.93 & 3.00 & 0.31 & 0.97 & 0.423 \\
\hline & Times & 2472.13 & 23.00 & 107.48 & 248.51 & $<0.001$ \\
\hline & Times $\times$ SAR & 22.89 & 69.00 & 0.33 & 0.77 & 0.915 \\
\hline & Times $\times R C \times S A R$ & 28.49 & 69.00 & 0.41 & 0.95 & 0.583 \\
\hline & Error & 238.75 & 552.00 & 0.43 & & \\
\hline \multirow[t]{7}{*}{ Soil $\mathrm{CO}_{2}$ fluxes } & $\mathrm{RC}$ & 59.65 & 1.00 & 59.65 & $10,170.22$ & $<0.001$ \\
\hline & SAR & 14.35 & 3.00 & 4.78 & 815.45 & $<0.001$ \\
\hline & $\mathrm{RC} \times \mathrm{SAR}$ & 0.08 & 3.00 & 0.03 & 4.46 & 0.013 \\
\hline & Times & 237.54 & 23.00 & 10.33 & 1573.07 & $<0.001$ \\
\hline & Times $\times$ SAR & 6.37 & 69.00 & 0.09 & 14.07 & $<0.001$ \\
\hline & Times $\times$ SAR $\times R C$ & 1.92 & 69.00 & 0.03 & 4.23 & $<0.001$ \\
\hline & Error & 3.62 & 552.00 & 0.01 & & \\
\hline \multirow[t]{7}{*}{ Annual mean soil respiration rate } & $\mathrm{RC}$ & 5.33 & 1.00 & 5.33 & $11,281.11$ & $<0.001$ \\
\hline & SAR & 1.24 & 3.00 & 0.41 & 878.23 & $<0.001$ \\
\hline & $\mathrm{RC} \times \mathrm{SAR}$ & 0.01 & 3.00 & 0.00 & 4.86 & 0.009 \\
\hline & Times & 0.52 & 1 & 0.52 & 1200.66 & $<0.001$ \\
\hline & Times $\times$ SAR & 0.19 & 3 & 0.06 & 143.03 & $<0.001$ \\
\hline & Times $\times$ SAR $\times R C$ & 0.02 & 3 & 0.01 & 15.67 & $<0.001$ \\
\hline & Error & 0.01 & 24 & 0.00 & & \\
\hline \multirow[t]{7}{*}{ Annual cumulative soil respiration } & $\mathrm{RC}$ & $673,061.58$ & 1 & $673,061.58$ & $25,420.13$ & $<0.001$ \\
\hline & SAR & $135,053.87$ & 3 & $45,017.96$ & 1700.23 & $<0.001$ \\
\hline & $\mathrm{RC} \times \mathrm{SAR}$ & 6120.43 & 3 & 2040.14 & 77.05 & $<0.001$ \\
\hline & Times & 2547.28 & 1 & 2547.28 & 113.30 & $<0.001$ \\
\hline & Times $\times$ SAR & 651.49 & 3 & 217.16 & 9.66 & $<0.001$ \\
\hline & Times $\times$ SAR $\times R C$ & 651.49 & 3 & 217.16 & 9.66 & $<0.001$ \\
\hline & Error & 539.59 & 24 & 22.48 & & \\
\hline \multirow[t]{7}{*}{ Soil pH } & $\mathrm{RC}$ & 1.272 & 1 & 1.272 & 351.883 & $<0.001$ \\
\hline & SAR & 0.475 & 3 & 0.158 & 43.785 & $<0.001$ \\
\hline & $\mathrm{RC} \times \mathrm{SAR}$ & 0.009 & 3 & 0.003 & 0.852 & 0.479 \\
\hline & Times & 1.44 & 3.00 & 0.48 & 69.66 & $<0.001$ \\
\hline & Times $\times$ SAR & 0.28 & 9.00 & 0.03 & 4.53 & $<0.001$ \\
\hline & Times $\times R C \times S A R$ & 0.08 & 9.00 & 0.01 & 1.30 & 0.251 \\
\hline & Error & 0.49 & 72.00 & 0.01 & & \\
\hline \multirow[t]{2}{*}{ Fine root biomass } & SAR & 0.51 & 3.00 & 0.17 & 8.48 & 0.003 \\
\hline & Times & 0.59 & 3.00 & 0.20 & 5.36 & 0.004 \\
\hline
\end{tabular}


Table 2 Repeated-measures ANOVA for the split-plot experiments. SS: sum of squares; MS: mean of squares (Continued)

\begin{tabular}{lllllll}
\hline Variable & Source & SS & df & MS & $F$-ratio & $P$ \\
\hline & Times $\times$ SAR & 0.95 & 9.00 & 0.11 & 2.88 & 0.012 \\
& Error & 1.33 & 36.00 & 0.04 & & \\
\hline
\end{tabular}

RC indicate respiration components $\left(R_{\mathrm{S}}\right.$ and $\left.R_{\mathrm{h}}\right)$. SAR indicate simulated acid rain

the T4.0, T3.25, and T2.5 treatments, respectively (Fig. 4A and B, Table 2).

The soil fine root biomass under different treatments was promoted by acid rain at the early stage of the experiment (April 2016) $(P<0.05)$ and increased by $20.98 \%, 17.48 \%$, and $20.28 \%$ in the UT4.0, UT3.25, and UT2.5 treatments compared with the control, respectively. At the later stage of the experiment (October 2017), the simulated acid rain inhibited the treatment and increased by $9.34 \%, 18.68 \%$, and $26.92 \%$ in the UT4.0, UT3.25, and UT2.5 treatments compared with the control, respectively (Fig. 4C, Table 2).

Significant differences were not observed in the soil microbial biomass carbon and microbial biomass nitrogen between trenched and untrenched treatments $(P>0.05)$ (Fig. 5A and $\mathrm{C}$ ). Urease activity was significantly different between the control and $\mathrm{pH} 2.5$ treatment $(P<0.01)$. Urease activity in the UT2.5 treatment was reduced by $28.85 \%$, while it was reduced by $18.16 \%$ and $32.80 \%$ in the
T3.25 and T2.5 treatments. Sucrase activity was also inhibited by acid rain. The sucrase activity in the UT3.25 and UT2.5 treatments were significantly reduced by $20.92 \%$ and $43.74 \%(P<0.05)$, respectively, while it was reduced by $25.86 \%$ and $30.08 \%(P<0.01)$ in the T3.25 and T2.5 treatments, respectively (Fig. 5B and D).

\section{Soil nutrients}

The soil organic $\mathrm{C}$ content and $\mathrm{C}: \mathrm{N}$ ratio were significantly increased by acid rain $(P<0.01)$. The soil organic $C$ content of the UT4.0, UT3.25, and UT2.5 treatments increased by $20.57 \%, 43.07 \%$, and $60.30 \%$ compared with the CK, respectively, while that of the T3.25 and T2.5 treatments increased by $47.32 \%$ and $47.40 \%$, respectively. The corresponding C:N ratio of the UT4.0, UT3.25, and UT2.5 treatments increased by $14.66 \%, 27.07 \%$, and $43.51 \%$, respectively, while that of the T3.25 and T2.5 treatments increased by $38.23 \%$ and $46.65 \%$, respectively. By contrast, the soil hydrolysable $\mathrm{N}$ and total $\mathrm{P}$ concentrations were
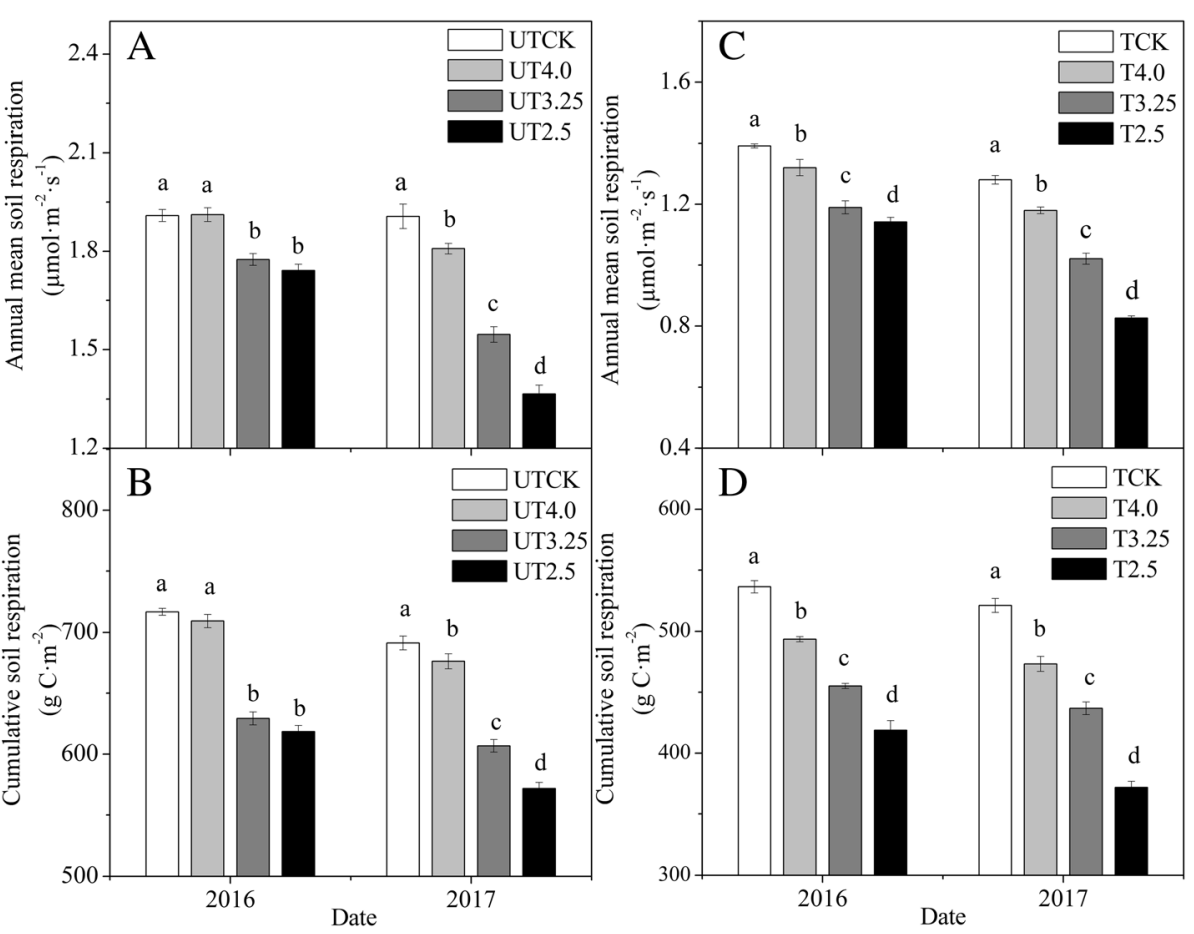

Fig. 2 Variation in the annual mean soil respiration rate under different treatments (A); variation in the cumulative soil respiration under the different treatments (B); variation in the annual mean heterotrophic respiration rate under different treatments $(C)$; and variation in the cumulative heterotrophic respiration under the different treatments (D). Vertical bars represent standard errors $(n=4)$. Different lowercase letters indicate significant difference between treatments $(P<0.05)$. UTCK, UT4.0, UT3.25, and UT2.5 indicate the control, pH 4.0, pH 3.25, and pH 2.5 simulated acid rain in the untrenched plots, respectively; TCK, T4.0, T3.25, and T2.5 indicate the control, pH 4.0, pH 3.25, and pH 2.5 simulated acid rain in the trenched plots, respectively 

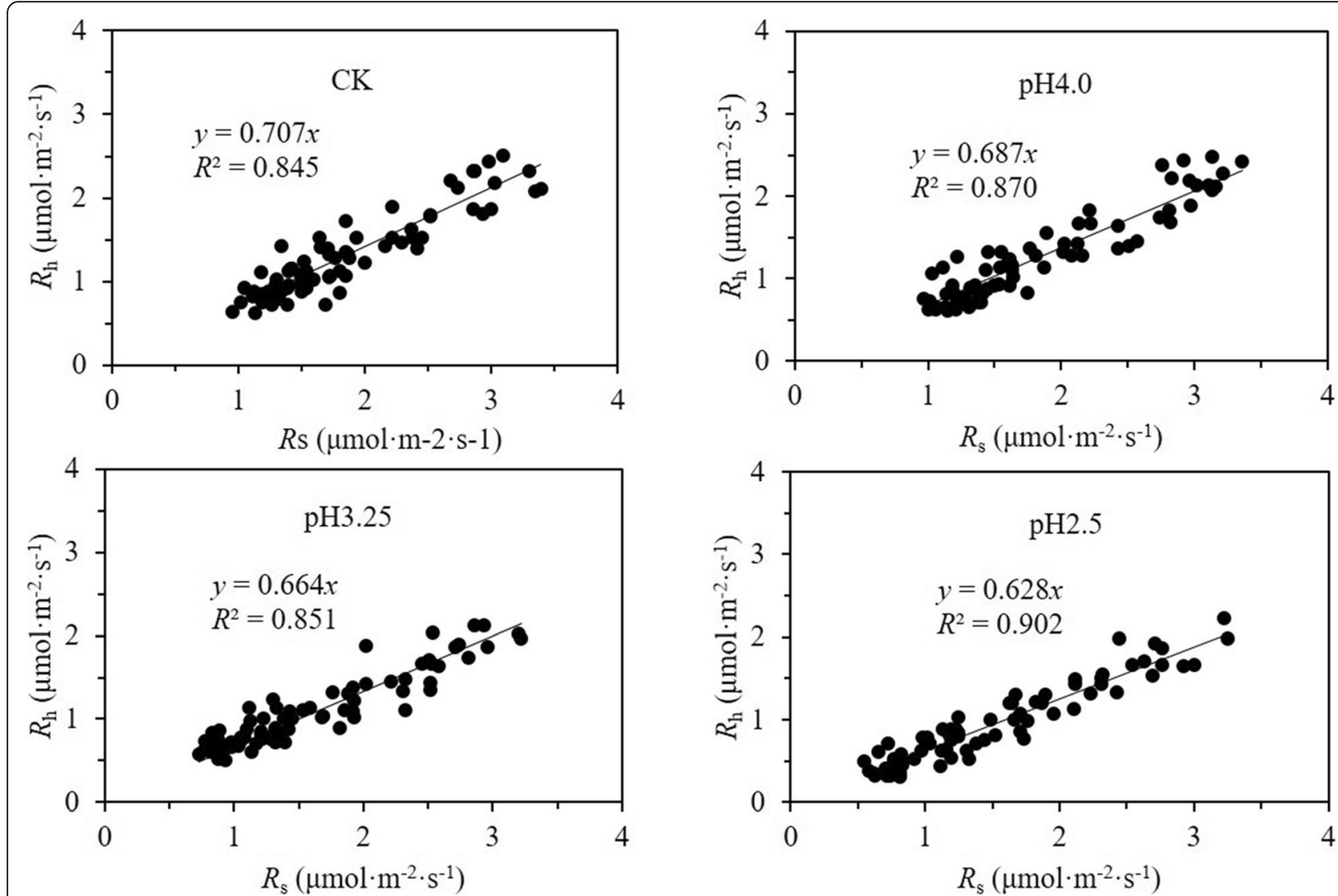

Fig. 3 Relationship between heterotrophic respiration $\left(R_{h}\right)$ and soil respiration $\left(R_{s}\right)$ under the different simulated acid rain treatments. All $P$ values for the regression lines are less than 0.01

significantly decreased by acid rain $(P<0.01)$. The hydrolysable N concentrations of the UT4.0, UT3.25, and UT2.5 treatments decreased by $14.17 \%, 29.80 \%$, and $27.44 \%$ compared with the CK, respectively, while that of the T3.25 and T2.5 treatments decreased by $38.64 \%$ and $15.70 \%$, respectively. The corresponding total $\mathrm{P}$ of the UT4.0, UT3.25, and UT2.5 decreased by $45.97 \%, 43.80 \%$, and $13.34 \%$, respectively, while that of the T4.0, T3.25, and T2.5 treatments increased by $46.01 \%, 49.28 \%$, and $13.89 \%$. Significant differences were not observed in the total $\mathrm{N}$ or available $\mathrm{P}$ between the different simulated acid rain treatments $(P>0.05$; Table 3$)$.

\section{Correlation analysis}

The seasonally varying soil respiration showed a highly significant exponential correlation with soil temperature in all simulated acid precipitation treatments $(P<0.01)$. The soil temperature at a depth of $5 \mathrm{~cm}$ explained $82.60 \%-95.2 \%$ of the seasonal variation in soil respiration. The soil Q10 values (temperature sensitivity) of the CK, T4.0, T3.25 and T2.5 treatments gradually increased with decreasing acidity. A significant quadratic function relationship was not observed between seasonally varying soil respiration and soil water content in the untrenched plots $(P>0.05)$. A significant quadratic function relationship was observed between heterotrophic respiration and soil water content in the trenched plots $(P<0.05)$, although all $R^{2}$ values were below 0.2 (Table 4). In addition, the two-factor model for soil temperature and soil moisture content had a higher $R^{2}$ value than the single-factor model (Table 4).

The results of the correlation analysis showed that soil respiration had a highly significant positive linear correlation with soil $\mathrm{pH}$, the fine root biomass and urease activity $\left(P<0.01 ; R^{2}=0.49,0.22\right.$ and 0.21 , respectively). In addition, soil respiration was significantly and positively linearly correlated with sucrase activity $\left(P<0.05 ; R^{2}=\right.$ 0.15). By contrast, soil respiration and $C: N$ ratio were highly significantly negatively linearly correlated $(P<0.01$; $\left.R^{2}=-0.32\right)$. A significant and negative linear correlation was observed between soil respiration and the organic $\mathrm{C}$ content $\left(P<0.05 ; R^{2}=-0.12\right.$; Fig. 6$)$.

\section{Discussion}

Effects of simulated acid rain on soil respiration

In this study, the repeated-measures ANOVA showed that acid rain had a significant cumulative effect on soil respiration and heterotrophic respiration (Fig. 1E and F). The effects of acid rain on soil respiration and heterotrophic 

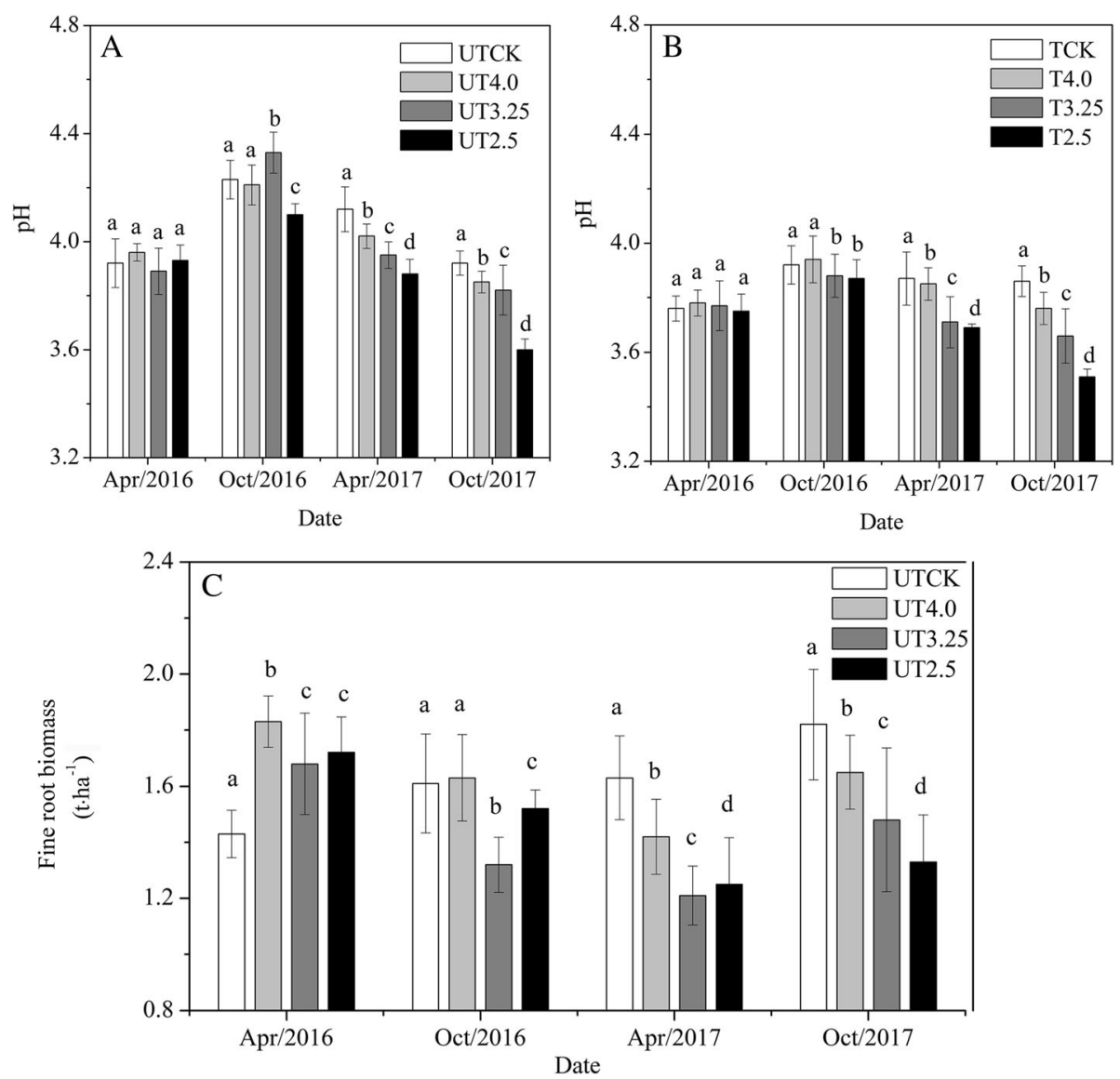

Fig. 4 Variation in the soil pH under different treatments in the untrenched plots (A); variation in soil pH under different treatments in the trenched plots (B); and variation in fine root biomass under different treatments (C). Vertical bars represent standard errors $(n=4)$. Different lowercase letters indicate significant differences between treatments $(P<0.05)$. UTCK, UT4.0, UT3.25, and UT2.5 indicate the control, pH 4.0, pH 3.25, and pH 2.5 simulated acid rain in the untrenched plots, respectively; TCK, T4.0, T3.25, and T2.5 indicate the control, pH 4.0, pH 3.25, and pH 2.5 simulated acid rain in the trenched plots, respectively

respiration were not obvious at the beginning of the experiment, but they gradually differed from the control. In 2016, the soil respiration in the untrenched plots was similar between the control and the $\mathrm{pH} 4.0$ treatment but markedly inhibited by the higher acidity of the simulated acid rain. Heterotrophic respiration in the trenched plots was significantly inhibited by all acid rain gradients in 2016. In 2017, soil respiration and heterotrophic respiration were significantly reduced by the simulated acid rain compared with the control levels. This observation is similar to the results of Liang et al. (2016) but inconsistent with the results of Chen et al. (2015), who found that simulated acid rain had no obvious promoting or inhibiting effects on soil respiration. The reason why the soil respiration of 2016 did not significantly differ between the control and the $\mathrm{pH} 4.0$ treatment was that the soil itself had a buffering effect on the input of acid rain and the acid substances would be partially offset. Because the decrease in soil $\mathrm{pH}$ was limited at the beginning of the experiment (Fig. 4A and B), its effects on soil microbes and plant roots would also be partially offset. In addition, in the initial stage of the experiment, $\mathrm{NO}_{3}{ }^{-}$as a nitrogen source promoted root growth and increased root biomass because of the simulated acid rain composed of sulphuric acid and nitric acid (Zhang et al. 2013) (Fig. 4C). The increase in root respiration counteracted the decrease in heterotrophic respiration, which resulted in no significant differences between the control and the $\mathrm{pH} 4.0$ treatment in 2016 (Tanikawa et al. 2014; $\mathrm{Hu}$ et al. 2015). In the following year (2017), the effects of acid rain continuously accumulated and resulted in the differences.

Soil respiration mainly comprises autotrophic respiration by roots and heterotrophic respiration by soil microbes. The effects of the simulated acid rain on soil respiration are a reflection of its combined effects on both types of respiration. The main reasons for the decrease in soil respiration by acid rain during 2016-2017 are as follows. 1) With the addition of acid rain, the acid-buffering capacity of the soil is offset and the soil is acidified, leading to decreases in $\mathrm{pH}$ (Fig. 4A and B). Soil acidification can lead to the release of 


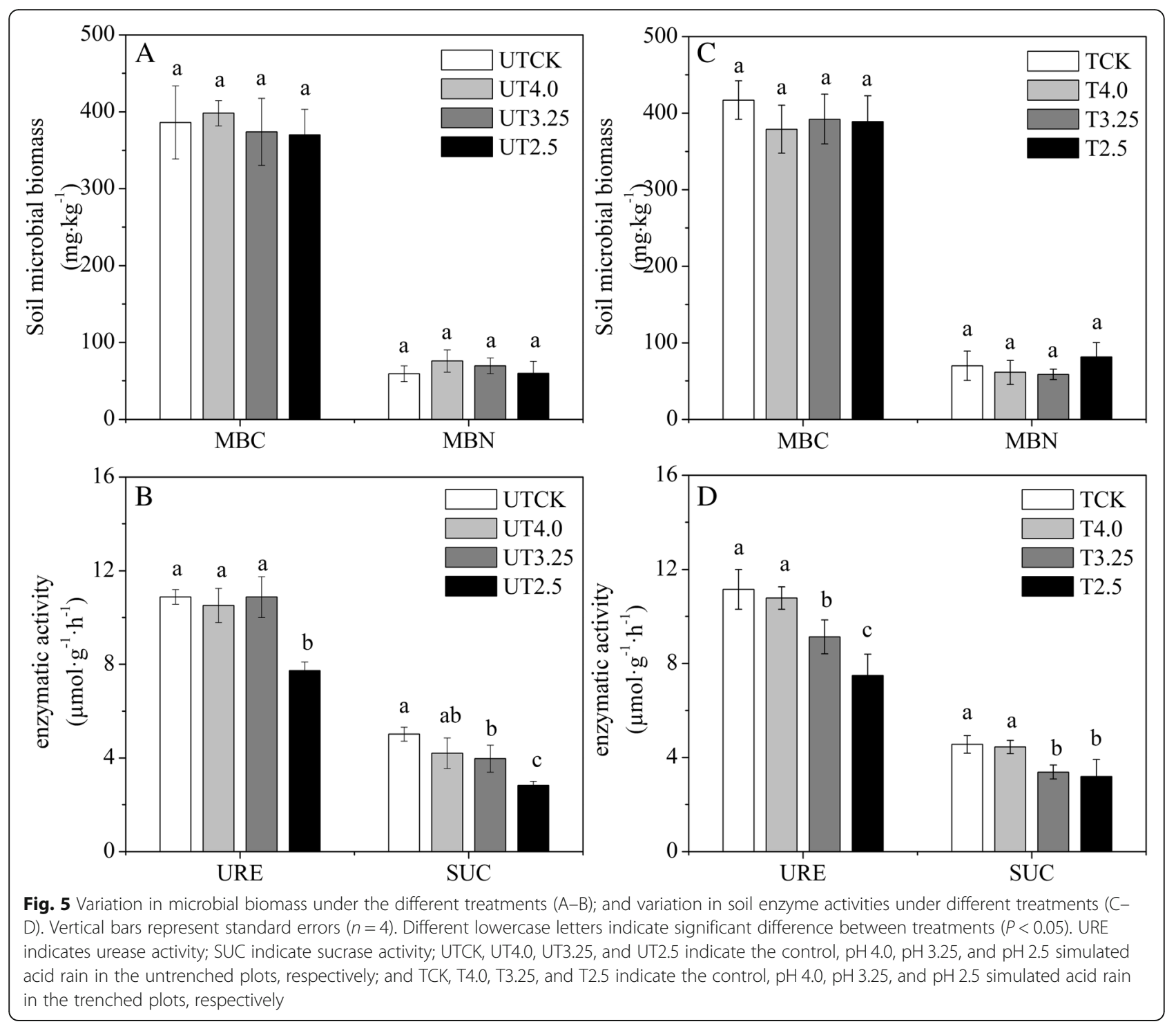

Table 3 Variation in soil organic C, total N, C:N ratio, hydrolysable N, available $\mathrm{P}$, and total P. Data are the mean \pm standard error

\begin{tabular}{lllllll}
\hline Treatment & Soil organic C $\left(\mathrm{mg}^{-1} \mathrm{~g}^{-1}\right)$ & Total N $\left(\mathrm{mg} \cdot \mathrm{g}^{-1}\right)$ & C:N ratio & Hydrolysable N $\left(\mathrm{mg} \cdot \mathrm{g}^{-1}\right)$ & Available P $\left(\mathrm{mg} \cdot \mathrm{kg}^{-1}\right)$ & Total P $\left(\mathrm{mg} \cdot \mathrm{g}^{-1}\right)$ \\
\hline UTCK & $18.17 \pm 3.19 \mathrm{a}$ & $1.46 \pm 0.24 \mathrm{a}$ & $12.41 \pm 0.32 \mathrm{a}$ & $0.21 \pm 0.01 \mathrm{a}$ & $1.62 \pm 0.77 \mathrm{a}$ & $0.41 \pm 0.03 \mathrm{a}$ \\
UT4.0 & $21.91 \pm 1.77 \mathrm{~b}$ & $1.54 \pm 0.16 \mathrm{a}$ & $14.23 \pm 0.24 \mathrm{~b}$ & $0.18 \pm 0.02 \mathrm{~b}$ & $1.5 \pm 0.54 \mathrm{a}$ & $0.22 \pm 0.04 \mathrm{~b}$ \\
UT3.25 & $25.99 \pm 3.61 \mathrm{c}$ & $1.65 \pm 0.22 \mathrm{a}$ & $15.77 \pm 0.49 \mathrm{c}$ & $0.15 \pm 0.02 \mathrm{c}$ & $1.34 \pm 0.59 \mathrm{a}$ & $0.23 \pm 0.02 \mathrm{~b}$ \\
UT2.5 & $25.61 \pm 3.04 \mathrm{~d}$ & $1.64 \pm 0.18 \mathrm{a}$ & $17.81 \pm 0.45 \mathrm{~d}$ & $0.15 \pm 0.01 \mathrm{c}$ & $1.41 \pm 0.80 \mathrm{a}$ & $0.36 \pm 0.03 \mathrm{c}$ \\
TCK & $19.76 \pm 2.18 \mathrm{a}$ & $1.49 \pm 0.17 \mathrm{a}$ & $13.26 \pm 0.47 \mathrm{a}$ & $0.22 \pm 0.01 \mathrm{a}$ & $1.66 \pm 0.71 \mathrm{a}$ & $0.39 \pm 0.03 \mathrm{a}$ \\
T4.0 & $20.84 \pm 2.58 \mathrm{a}$ & $1.59 \pm 0.21 \mathrm{a}$ & $13.11 \pm 0.28 \mathrm{a}$ & $0.24 \pm 0.01 \mathrm{a}$ & $1.83 \pm 0.70 \mathrm{a}$ & $0.21 \pm 0.02 \mathrm{~b}$ \\
T3.25 & $29.11 \pm 1.53 \mathrm{~b}$ & $1.59 \pm 0.07 \mathrm{a}$ & $18.33 \pm 0.36 \mathrm{~b}$ & $0.14 \pm 0.01 \mathrm{~b}$ & $1.59 \pm 0.84 \mathrm{a}$ & $0.20 \pm 0.04 \mathrm{~b}$ \\
T2.5 & $29.12 \pm 3.04 \mathrm{~b}$ & $1.50 \pm 0.15 \mathrm{a}$ & $19.44 \pm 0.44 \mathrm{~b}$ & $0.19 \pm 0.02 \mathrm{c}$ & $2.02 \pm 0.51 \mathrm{a}$ & $0.34 \pm 0.04 \mathrm{c}$ \\
\hline
\end{tabular}

Values followed by different letters are significantly different between treatments $(P<0.05)$. UTCK, UT4.0, UT3.25, and UT2.5 indicate control, $\mathrm{pH} 4.0$, pH 3.25, and $\mathrm{pH} 2.5$ simulated acid rain in the untrenched plots, respectively; TCK, T4.0, T3.25, and T2.5 indicate the control, pH 4.0, pH 3.25, and pH 2.5 simulated acid rain in the trenched plots, respectively 
Table 4 Relationship of the soil respiration and the heterotrophic respiration with 5-cm soil temperature or moisture content under different simulated acid rain treatments

\begin{tabular}{|c|c|c|c|c|c|c|c|c|c|c|c|c|}
\hline \multirow[t]{3}{*}{ Treatment } & \multicolumn{4}{|c|}{ 5-cm soil temperature } & \multicolumn{4}{|c|}{ 5-cm soil water content } & \multirow{2}{*}{\multicolumn{4}{|c|}{$\frac{\text { 5-cm soil temperature and water content }}{\text { Fitting equation }\left(y=f \times \mathrm{e}^{g \times T} \times M^{h}\right)}$}} \\
\hline & \multicolumn{3}{|c|}{$\overline{\text { Fitting equation }\left(y=a \times e^{b \times T}\right)}$} & \multirow[t]{2}{*}{ Q10 } & \multicolumn{4}{|c|}{ Fitting equation $\left(y=c M^{2}+d M+e\right)$} & & & & \\
\hline & $\bar{a}$ & $b$ & $R^{2}$ & & $a$ & $b$ & c & $R^{2}$ & $\bar{a}$ & $b$ & $c$ & $R^{2}$ \\
\hline UTCK & 0.69 & 0.06 & $0.95^{* *}$ & 1.90 & 0.03 & -1.59 & 21.02 & 0.11 & 1.96 & 0.06 & -0.33 & $0.96^{* *}$ \\
\hline UT4.0 & 0.62 & 0.07 & $0.94^{* *}$ & 1.99 & 0.03 & -1.53 & 20.51 & 0.09 & 2.30 & 0.07 & -0.41 & $0.96^{* *}$ \\
\hline UT3.25 & 0.51 & 0.07 & $0.94^{* *}$ & 2.10 & 0.03 & -1.66 & 21.81 & 0.11 & 1.46 & 0.07 & -0.33 & $0.95^{* *}$ \\
\hline UT2.5 & 0.42 & 0.08 & $0.91^{* *}$ & 2.27 & 0.04 & -1.82 & 23.69 & 0.11 & 1.58 & 0.08 & -0.41 & $0.92^{* *}$ \\
\hline TCK & 0.47 & 0.07 & $0.86^{* *}$ & 1.93 & 0.10 & -4.57 & 54.75 & 0.23 & 1.27 & 0.07 & -0.31 & $0.87^{* *}$ \\
\hline T4.0 & 0.37 & 0.08 & $0.94^{* *}$ & 2.16 & 0.11 & -5.34 & 63.40 & $0.28^{*}$ & 0.60 & 0.08 & -0.15 & $0.94^{* *}$ \\
\hline T3.25 & 0.38 & 0.07 & $0.92^{* *}$ & 1.97 & 0.09 & -4.17 & 50.03 & $0.28^{*}$ & 1.98 & 0.07 & -0.52 & $0.93^{* *}$ \\
\hline T2.5 & 0.28 & 0.08 & $0.83^{* *}$ & 2.25 & 0.10 & -4.54 & 54.03 & $0.29^{*}$ & 0.55 & 0.08 & -0.21 & $0.83^{* *}$ \\
\hline
\end{tabular}

In the equations, $y$ represents the soil respiration rate $\left(\mu \mathrm{mol} \cdot \mathrm{m}^{-2} \cdot \mathrm{s}^{-1}\right), T$ represents $5-\mathrm{cm}$ soil temperature $\left({ }^{\circ} \mathrm{C}\right), M$ represents 5 - $\mathrm{cm}$ soil moisture content, and $a, b, c$, $d, e, f, g$, and $h$ are constants. UTCK, UT4.0, UT3.25, and UT2.5 indicate control, $\mathrm{pH} 4.0, \mathrm{pH} 3.25$, and pH 2.5 simulated acid rain in the untrenched plots, respectively TCK, T4.0, T3.25, and T2.5 indicate the control, $\mathrm{pH} 4.0, \mathrm{pH} 3.25$, and $\mathrm{pH} 2.5$ simulated acid rain in the trenched plots, respectively. ${ }^{*}$ significant correlation $(P<0.05)$; ** highly significant correlation $(P<0.01)$

some harmful elements, for example, the activation and release of activated aluminium, which has toxic effects on plant roots and lowers the root biomass (Esher et al. 1992; Hirano and Hijii 1998). The fine root biomass of the $\mathrm{pH}$ 4.0, $\mathrm{pH} 3.25$, and $\mathrm{pH} 2.5$ treatments was significantly reduced compared with the control levels (Fig. 4C). As root respiration contributed to $45.8 \%$ of the total soil respiration in forest ecosystems on average, soil respiration decreased with decreasing root biomass (Hanson et al. 2000). 2) Soil acidification can affect the process of soil $\mathrm{C}$ and $\mathrm{N}$ cycles, such as organic mineralization, ammoniation, and nitrification, changing the soil environment and affecting microbial respiration (Cheng et al. 2013; Zhu et al. 2013). In the current study, the soil OC content
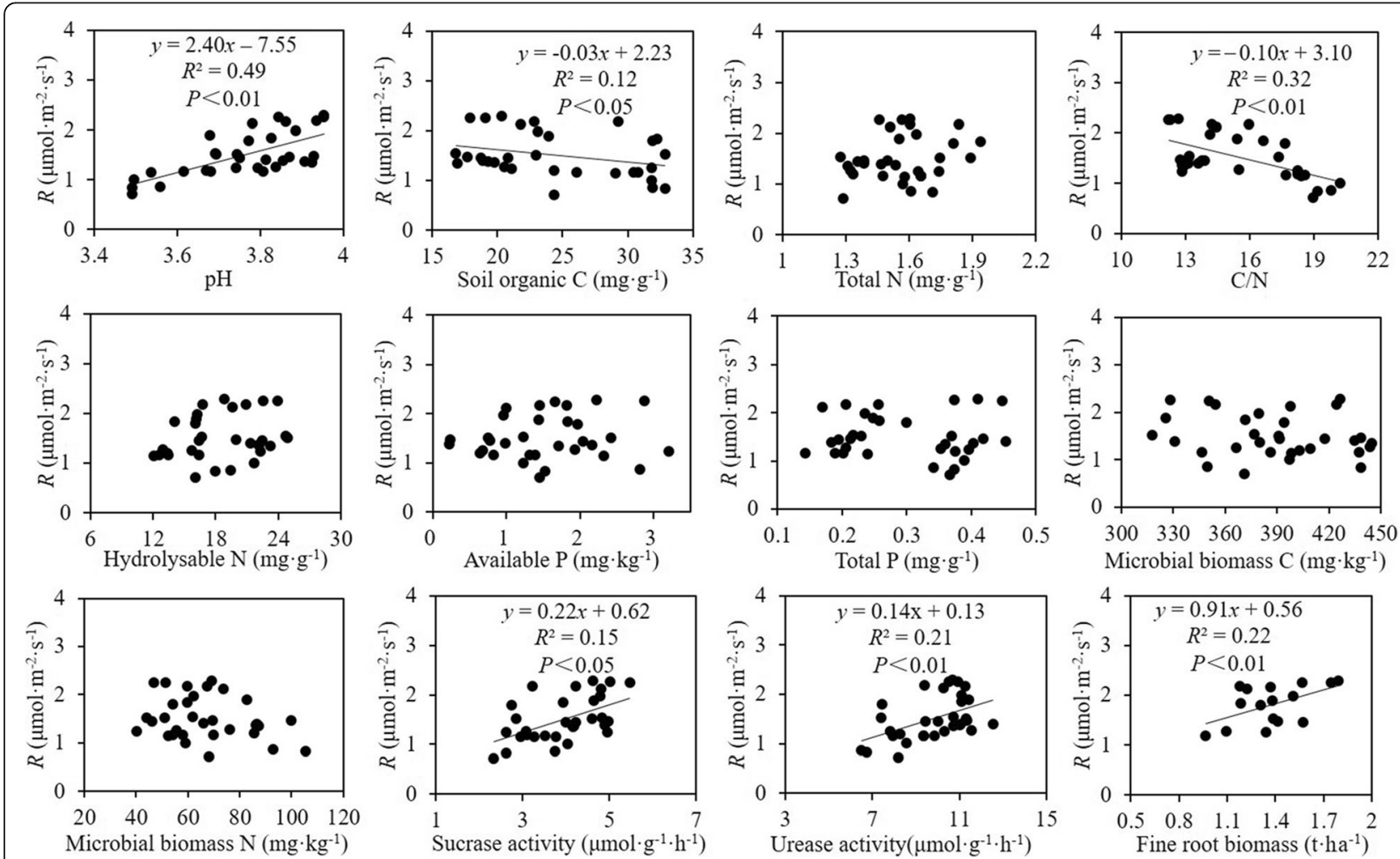

Fig. 6 Relationship between the mean soil respiration rate in October 2017 and soil properties. $\mathrm{R}$ represents the soil $\mathrm{CO}_{2}$ fluxes $\left(\mu \mathrm{mol} \cdot \mathrm{m}^{-2} \cdot \mathrm{s}^{-1}\right.$ ) in the untrenched plots and trenched plots. The graphs without trend lines represent nonsignificant linear relationships 
significantly increased in the $\mathrm{pH} 4.0, \mathrm{pH} 3.25$, and $\mathrm{pH} 2.5$ treatments compared with the control levels, whereas the corresponding hydrolysable $\mathrm{N}$ concentrations also decreased significantly (Table 3 ). In addition, variation in the soil $\mathrm{C}: \mathrm{N}$ ratio could affect the release of nutrients from the microbial decomposition of organic matter. (Hessen et al. 2004). In our study, the soil C:N ratios of the simulated acid rain treatments were significantly higher than the control level (Table 3). The increase in soil C:N ratio under the addition of acid rain resulted in $\mathrm{N}$ limitation during the decomposition of organic matter by microbes, thus affecting heterotrophic respiration and inhibiting the total soil respiration (Knorr et al. 2005). This result was also supported by a significant negative correlation between the soil respiration rate and soil $\mathrm{C}: \mathrm{N}$ ratio. 3) Acid rain changes soil properties, and the variation in the soil nutrient environment can affect the community and quantity of microbes, whereas the microbes need to readapt to the soil microenvironment (Wan et al. 2015). Herein, we found no significant differences in soil microbial biomass $\mathrm{C}$ and $\mathrm{N}$ between the treatments (Fig. 5A and $\mathrm{C}$ ), but the urease activity of the UT2.5, T3.25, and T2.5 treatments was significantly reduced, and the sucrase activity of the UT3.25, UT2.5, T3.25, and T2.5 treatments was significantly reduced (Fig. 5B and D). Soil enzyme activity is a direct expression of the metabolic requirement and available nutrients for microbial communities (Caldwell 2005; Ling et al. 2010). Therefore, we speculated that acid rain mainly affected the soil microbial community structure, inhibited the enzymes involved in the decomposition of respiratory substrates, and affected microbial utilization of respiratory substrates, thus decreasing heterotrophic respiration in soil respiration (Iqbal et al. 2010) . In conclusion, soil acidification under simulated acid rain affected the root growth and organic matter decomposition, altered the process of $\mathrm{C}$ and $\mathrm{N}$ cycles, and changed the soil properties, thus affecting the microbial community structure and substrate utilization as well as soil respiration (Hanson et al. 2000). In our study, the significant linear relationships between the soil respiration rate and the soil $\mathrm{pH}$, fine root biomass, urease activity, sucrase activity, soil organic $\mathrm{C}$, and $\mathrm{C}: \mathrm{N}$ ratio also illustrated this point (Fig. 6).

At present, few studies have focused on the effects of acid rain on the components of soil respiration, especially on the relationship between autotrophic and heterotrophic parts. Chen et al.'s study (Chen et al. 2015) found that simulated acid rain increased the proportion of heterotrophic respiration in total soil respiration, which indicated that simulated acid rain reduced the proportion of autotrophic respiration; however, these findings were inconsistent with the results of this study. The increase in acid rain intensity decreased the proportion of heterotrophic respiration, and the degree of reduction increased as the $\mathrm{pH}$ of the simulated acid rain decreased (Fig. 3). The mechanism of autotrophic respiration was different from that of heterotrophic respiration, and the feedback system on acid rain was also different (Wu et al. 2015). In this study, the simulated acid rain treatments reduced the proportion of heterotrophic respiration, meaning that an increase in the acid rain intensity more strongly inhibited heterotrophic respiration, which indicated that the response of soil microorganisms to soil environmental changes was stronger than that of root systems.

\section{Effects of temperature and moisture}

The significant seasonal variation in soil temperature $(P<0.01)$ together with a significant exponential function relationship between soil temperature and soil respiration indicated that soil temperature could explain the seasonal variation in soil respiration. However, the simulated acid rain had no significant effects on soil temperature or moisture, indicating that the temperature and moisture contributed little to differences in soil respiration under simulated acid rain. In our study, the temperature sensitivity coefficient of soil respiration and heterotrophic respiration varied from 1.90-2.27 (Table 4 ), which fell in the range of the temperature sensitivity coefficient of soil respiration in mixed coniferousbroadleaved forests in China (1.82-3.74) reported by Peng et al. (2009). During our study period, the Q10 values of soil respiration and heterotrophic respiration increased gradually with decreasing acidity (Table 4). This result is inconsistent with previous findings that acid rain had no significant effects on the temperature sensitivity coefficient of soil respiration (Chen et al. 2015) and that acid rain lowered the temperature sensitivity coefficient of soil respiration (Liang et al. 2016). The increase in the temperature sensitivity coefficient may be attributable to simultaneous increases in the temperature sensitivity coefficient of root respiration and microbial respiration or to the greater increase in the temperature sensitivity coefficient of microbial respiration relative to the decrease in that of root respiration. It is highly probable that acid rain affected the quality of the respiratory substrate and increased the temperature sensitivity of microbial respiration, thereby changing the sensitivity of soil respiration (Craine et al. 2007). The respiratory substrates are decomposed during soil respiration. Generally, it is more difficult to decompose relatively complex substrates, and the energy required is also increased. Moreover, the activation energy is thus increased as shown by an increase in temperature sensitivity. In the present study, the simulated acid rain treatments increased the C:N ratio of the soil (Table 3); therefore, the substrates supplied to the microbes were not readily decomposed, and their activation energy was 
increased as manifested by the increase in temperature sensitivity. In addition, the simulated acid rain may affect the temperature sensitivity of the roots. Although the simulated acid rain reduced the root biomass compared with the control (Fig. 4C), the relationship between the root biomass and temperature sensitivity of root respiration remains unclear. Our next step is to distinguish the temperature sensitivity of soil microbial and root respiration under simulated acid rain.

In this study, a significant correlation was not observed between the soil moisture content and soil respiration. The water-heat two-factor model improved the $R^{2}$ value compared with the single-factor model, although the effect was weak (Table 4). This finding was related to the small seasonal variability of the soil moisture content, which had no extreme values during the measurement period; on the other hand, soil temperature could explain most of the seasonal variation in soil respiration, whereas the soil moisture content had little effect.

\section{Limitations of the study}

'Trenching' is a method that has a precedent in the soil respiration literature. Although it is easily accomplished, the method presents certain drawbacks. Soil moisture on trenched plots is usually higher, and additional sources of carbon dioxide from trenched plots may emerge because of decaying dead roots (Eugenio et al. 2010). In addition, some autotrophic respiration may be assigned to heterotrophic respiration because of roots below a depth of $40 \mathrm{~cm}$ (Lavigne et al. 2003). These factors can lead to overestimated $R_{\mathrm{h}}$ values. In some cases, when the soil moisture content dropped below $12 \%$, water limitations for soil $\mathrm{CO}_{2}$ emissions were clear (Orchard and Cook 1983; Linn and Doran 1984; Savage et al. 2013). In our study, however, the soil moisture in the forest system was not a limiting factor for soil respiration. The regression analysis also showed that relative to temperature, the effect of water on soil respiration was very limited. With regard to the additional $\mathrm{CO}_{2}$ caused by dead roots, we constructed the trenched plots for 6 months before the experiment to ensure the decomposition of dead roots. Moreover, the whole experiment lasted 2 years to ensure that the effect of dead roots on results was minimized. Thus, the extent of the error with our trenching depth was probably small. First, respiration occurred mainly near the soil surface because the large majority of fine root biomass and debris were located at the upper $5-10 \mathrm{~cm}$ and because the contribution of carbon dioxide from deep soil was likely to be small. Second, the soil layer in our study area was thinner. When the depth of trenching was more than $40 \mathrm{~cm}$, soil parent material composed of rock weathering debris emerged, and roots were rare. Therefore, in the two-year experiment in our study area, trenching is a viable option for relatively accurately estimating heterotrophic respiration.

\section{Conclusions}

Our results showed that acid rain had a significant $\mathrm{cu}-$ mulative effect on soil respiration and heterotrophic respiration. In 2016, similar soil respiration was found in the control versus the $\mathrm{pH}$ of 4.0 treatment, although the higher acidity of the simulated acid rain significantly inhibited soil respiration. In 2017, soil respiration and heterotrophic respiration were significantly decreased by acid rain. Although the soil temperature could explain the seasonal variation in soil $\mathrm{CO}_{2}$ fluxes, there were no significant differences in the soil temperature and moisture under different simulated acid rain treatments. The simulated acid rain treatments enhanced the temperature sensitivity of soil respiration and heterotrophic respiration. Moreover, our study showed that the simulated acid rain significantly increased the soil organic $\mathrm{C}$ content and C:N ratio, lowered the hydrolysable $\mathrm{N}$ and the total $\mathrm{P}$ concentration, and lowered the soil $\mathrm{pH}$ and fine root biomass at the later stage of the experiment. Both urease and sucrase activities were significantly reduced in the higher-acidity treatments. The microbial biomass $\mathrm{C}$ and $\mathrm{N}$ had no significant differences between the simulated acid rain treatments. The soil respiration rate was significantly positively correlated with soil $\mathrm{pH}$, fine root biomass, and urease and sucrase activity and was significantly negatively correlated with the soil organic $\mathrm{C}$ and $\mathrm{C}: \mathrm{N}$ ratio. Therefore, the soil temperature and moisture contributed little to differences in soil respiration under simulated acid rain. The variation in soil properties caused by soil acidification inhibited the microbial utilization of substrates, which was the main cause of the differences in respiration.

\section{Abbreviations}

ANOVA: analysis of variance; $\mathrm{R}$ : soil $\mathrm{CO}_{2}$ flux; $\mathrm{RC} \times \mathrm{SAR}$ : interaction between respiration components and simulated acid rain; RC: respiration components $\left(R_{\mathrm{s}}\right.$ and $\left.R_{\mathrm{h}}\right) ; R_{\mathrm{h}}$ : heterotrophic respiration; $R_{\mathrm{s}}$ : soil respiration; SAR: simulated acid rain; SM: $5-\mathrm{cm}$ soil moisture content; $S T$ : $5-\mathrm{cm}$ soil temperature; SUC: sucrase activity; T2.5: $\mathrm{pH} 2.5$ simulated acid rain treatment in the trenched plots; T3.25: $\mathrm{pH} 3.25$ simulated acid rain treatment in the trenched plots; T4.0: pH 4.0 simulated acid rain treatment in the trenched plots; TCK: control treatment in the trenched plots; URE: urease activity; UT2.5: pH 2.5 simulated acid rain treatment in the untrenched plots; UT3.25: $\mathrm{pH} 3.25$ simulated acid rain treatment in the untrenched plots; UT4.0: $\mathrm{pH} 4.0$ simulated acid rain treatment in the untrenched plots; UTCK: control treatment in the untrenched plots

\section{Acknowledgements}

We are grateful to the Chongqing Forestry Administration for the permission of our sampling and transplanting in Jinyun Shan National Nature Reserve, to Bureau of Jinyun Shan National Nature Reserve for the venues

supplement and logistical support during our research.

\section{Authors' contributions}

YL conceived and designed the study. YW and YW revised and perfected the design of the experiments. $Y L$ and BW performed the experiments. $Y L$ wrote the paper. BW and YW reviewed and edited the manuscript. All authors read and approved the manuscript. 


\section{Funding}

The study was funded by the "Forestry Science and Technology Research Project (2017-02)" and "the Fundamental Research Funds for the Central Universities (2015ZCQ-SB-01)" in China.

\section{Availability of data and materials}

The datasets used and/or analysed during the current study are available from the corresponding author on reasonable request.

\section{Ethics approval and consent to participate}

Not applicable.

\section{Consent for publication}

Not applicable.

\section{Competing interests}

The authors declare that they have no competing interests.

\section{Received: 8 January 2019 Accepted: 20 June 2019}

Published online: 02 July 2019

\section{References}

Aber J, McDowell W, Nadelhoffer K, Magill A, Berntson G, Kamakea M, McNulty S, Currie W, Rustad L, Fernandez I (1998) Nitrogen saturation in temperate forest ecosystems hypotheses revisited. Bioscience 48(11):921-934

Bao S (2000) Soil and agricultural chemistry analysis, 3rd edn. China Agriculture Press, Beijing, pp 39-97

Bowden RD, Davidson E, Savage K, Arabiaa C, Steudlerc P (2004) Chronic nitrogen additions reduce total soil respiration and microbial respiration in temperate forest soils at the Harvard Forest. Forest Ecol Manag 196(1):0-56

Brown S, Lenart M, Mo J (1995) Structure and organic matter dynamics of a human-impacted pine forest in a MAB reserve of subtropical China. Biotropica 27(3):276-289

Busch G, Lammel G, Beese FO, Feichter J, Dentener FJ, Roelofs G (2001) Forest ecosystems and the changing patterns of nitrogen input and acid deposition today and in the future based on a scenario. Environ Sci Pollut Res Int 8(2):95-102

Caldwell BA (2005) Enzyme activities as a component of soil biodiversity: a review. Pedobiologia 49:637-644

Chen S, Zhang X, Liu Y, Hu Z, Shen X, Ren J (2015) Simulated acid rain changed the proportion of heterotrophic respiration in soil respiration in a subtropical secondary forest. Appl Soil Ecol 86:148-157

Cheng Y, Wang J, Mary B, Zhang JB, Cai ZC, Chang SX (2013) Soil pH has contrasting effects on gross and net nitrogen mineralizations in adjacent forest and grassland soils in Central Alberta, Canada. Soil Biol Biochem 57:848-857

Craine JM, Morrow C, Fierer N (2007) Microbial nitrogen limitation increases decomposition. Ecology 88(8):2105-2113

Esher RJ, Marx DH, Ursic SJ, Baker RL, Brown LR, Coleman DC (1992) Simulated acid rain effects on fine roots, ectomycorrhizae, microorganisms, and invertebrates in pine forests of the southern United States. Water Air Soil Pollut 61(3-4):269-278

Eugenio D, Schindlbacher A, Pfeffer M, Zechmeister BS, Agustín R (2010) Root trenching: a useful tool to estimate autotrophic soil respiration? A case study in an Austrian mountain forest. Eur J Forest Res 129(1):101-109

Gopal M, Gupta A, Arunachalam V, Magu SP (2007) Impact of azadirachtin, an insecticidal allelochemical from neem on soil microflora, enzyme and respiratory activities. Bioresour Technol 98:3154-3158

Gu Y, Wang P, Kong CH (2009) Urease, invertase, dehydrogenase and polyphenoloxidase activities in paddy soil influenced by allelopathic rice variety. Eur J Soil Biol 45(5-6):436-441

Guo J, Yang Z, Lin C, Liu X, Chen G, Yang Y (2016) Conversion of a natural evergreen broadleaved forest into coniferous plantations in a subtropical area: effects on composition of soil microbial communities and soil respiration. Biol Fert Soil 52(6):799-809

Guo P (2016) Characteristics of acid deposition and its effects on forest soil in the three gorges reservoir area. Dissertation, Beijing: Beijing Forestry University

Guo P, Wang Y, Zhang H, Wang B, Hu B (2015) The impact of acid deposition on china's three gorges reservoir. Pol J Environ Stud 24(6):2411-2419

Hanson PJ, Edwards NT, Garten CT, Andrews JA (2000) Separating root and soil microbial contributions to soil respiration: a review of methods and observations. Biogeochemistry 48(1):115-146
Hashimoto S, Carvalhais N, Ito A, Migliavacca M (2015) Global spatiotemporal distribution of soil respiration modeled using a global database. Biogeosciences 12:4121-4132

Hessen DO, Ågren Gl, Anderson TR, Elser JJ, De Ruiter PC (2004) Carbon sequestration in ecosystems: the role of stoichiometry. Ecology 85(5): 1179-1192

Hirano Y, Hijii N (1998) Effects of low pH and aluminum on root morphology of Japanese red cedar saplings. Environ Poll 101(3):339-347

Hu B, Wang YQ, Wang YJ, Guo P, Liu CX, Tang XF, Sun SQ (2015) Effects of simulated nitrogen deposition on soil acidification and soil buffering capacity. Res Environ Sci 28(3):418-424

Huang XF, Li X, He LY, Feng N, Hu M, Niu YW, Zeng LW (2010) 5-year study of rainwater chemistry in a coastal mega-city in South China. Atm Res 97(1-2):185-193

labal J, Hu R, Feng M, Lin S, Malghani S, Ali IM (2010) Microbial biomass, and dissolved organic carbon and nitrogen strongly affect soil respiration in different land uses: a case study at three gorges reservoir area, South China. Agric Ecosyst Environ 137(3-4):294-307

Jian J, Steele MK, Day SD, Thomas RQ, Hodges SC (2018) Measurement strategies to account for soil respiration temporal heterogeneity across diverse regions. Soil Biol Biochem 125:167-177

Kandeler E, Tscherko D, Spiegel H (1999) Long-term monitoring of microbial biomass, $\mathrm{N}$ mineralisation and enzyme activities of a Chernozem under different tillage management. Biol Fert Soil 28(4):343-351

Knorr M, Frey SD, Curtis PS (2005) Nitrogen additions and litter decomposition: a meta-analysis. Ecology 86(12):3252-3257

Kuperman RG (1996) Relationships between soil properties and community structure of soil macroinvertebrates in oak-hickory forests along an acidic deposition gradient. Appl Soil Ecol 4(2):125-137

Lavigne MB, Boutin R, Foster RJ, Goodine G, Bernier PY, Robitaille G (2003) Soil respiration responses to temperature are controlled more by roots than by decomposition in balsam fir ecosystems. Can J For Res 33(9):1733-1753

Li YM (2009) Research on rainfall redistribution function of mixed broadleafconifer forest in Jinyun Mountain. Dissertation, Beijing: Beijing Forestry University

Liang G, Hui D, Wu X, Wu J, Liu J, Zhou G, Zhang D (2016) Effects of simulated acid rain on soil respiration and its components in a subtropical mixed conifer and broadleaf forest in southern China. Environ Sci Process Impact 18(2):246-255

Ling DJ, Huang QC, Ouyang Y (2010) Impacts of simulated acid rain on soil enzyme activities in a latosol. Ecotoxicol Environ Safety 73(8):1914-1918

Linn DM, Doran JW (1984) Effect of water-filled pore space on carbon dioxide and nitrous oxide production in tilled and nontilled soils. Soil Sci Soc Am J 48(3):1267-1272

Liu GS (1996) Soil physicochemical analysis and description of soil profiles. China Normative Press, Beijing

Lu RK (1999) Analysis methods of soil science and agricultural chemistry. Agriculture Science and Technology Press, Beijing

Lv Y, Wang CY, Jia YY, Wang WW, Ma X, Du J, Pu GZ, Tian XJ (2014) Effects of sulfuric, nitric, and mixed acid rain on litter decomposition, soil microbial biomass, and enzyme activities in subtropical forests of China. Appl Soil Ecol 79:1-9

Meldahll R, Chappelka AHHC, Lockaby BG, Thornton F, Wright LM (1990) The influence of acid precipitation and ozone on nitrogen nutrition of young loblolly pine. Water Air Soil Poll 54(1):135-142

Mo J, Brown S, Xue J, Fang YT, Li Z, Li DJ, Dong SF (2007) Response of nutrient dynamics of decomposing pine (Pinus massoniana) needles to simulated $\mathrm{N}$ deposition in a disturbed and a rehabilitated forest in tropical China. Ecol Res 22(4):649-658

Nannipieri P, Ceccanti B, Cervelli S, Matarese E (1980) Extraction of phosphatase, urease, proteases, organic carbon, and nitrogen from soil. Soil Sci Soc Am J 44(2):1011-1016

Orchard VA, Cook FJ (1983) Relationship between soil respiration and soil moisture. Soil Biol Biochem 15(4):447-453

Ouyang XJ, Zhou GY, Huang ZL, Liu JX, Zhang DQ, Li J (2008) Effect of simulated acid rain on potential carbon and nitrogen mineralization in forest soils. Pedosphere 18(4):503-514

Peng S, Piao S, Wang T, Sun J, Shen Z (2009) Temperature sensitivity of soil respiration in different ecosystems in China. Soil Biol Biochem 41(5):1008-1014

Savage K, Davidson EA, Tang JW (2013) Diel patterns of autotrophic and heterotrophic respiration among phenological stages. Glob Chang Biol 19(4): $1151-1159$ 
Tang X, Wang B, Wang Y, Wang Y (2015) Effect of simulated acid rain with different acidities on photosynthetic characteristics of two broad-leaved trees in Jinyun Mountain of Chongqing. J Plant Res Environ 24(04):45-51

Tanikawa T, Sobue A, Hirano Y (2014) Acidification processes in soils with different acid buffering capacity in Cryptomeria japonica and Chamaecyparis obtusa forests over two decades. Forest Ecol Manag 334:284-292

Turner DP, Tingey DT (1990) Foliar leaching and root uptake of ca, $\mathrm{mg}$ and $\mathrm{K}$ in relation to acid fog effects on Douglas-fir. Water Air Soil Poll 49(1-2):205-214

Wan X, Huang Z, He Z, Yu Z, Wang M, Davis MR, Yang Y (2015) Soil C: N ratio is the major determinant of soil microbial community structure in subtropical coniferous and broadleaf forest plantations. Plant Soil 387(1-2):103-116

Wei W, Weile C, Shaopeng W (2010) Forest soil respiration and its heterotrophic and autotrophic components: global patterns and responses to temperature and precipitation. Soil Biol Biochem 42(8):1236-1244

Wu D, Zhang R, Gao SH, Fu X, Deng HB, Shao GF, Zhang XD (2015) Effects of simulated nitrogen deposition on the each component of soil respiration in the Populus L. plantations in a riparian zone of the mid-lower Yangtze river. Acta Ecol Sin 35(3):717-724

Yu L (2015) Characteristics of soil respiration and its response to impact factors in typical forests at Jinyun Mountain. Dissertation, Beijing: Beijing Forestry University

Zhang JE, Ouyang Y, Ling DJ (2007) Impacts of simulated acid rain on cation leaching from the latosol in South China. Chemosphere 67(11):2131-2137

Zhang R, Wang Y, Jin GQ, Zhou ZC, Feng ZP (2013) Nitrogen addition affects root growth, phosphorus and nitrogen efficiency of three provenances of Schima superba in barren soil. Acta Ecol Sin 33(12):611-621

Zhang YL, Lee XQ, Cao F (2011) Chemical characteristics and sources of organic acids in precipitation at a semi-urban site in Southwest China. Atm Environ 45(2):413-419

Zhu T, Meng T, Zhang J, Yin Y, Cai Z, Yang W, Zhong W (2013) Nitrogen mineralization, immobilization turnover, heterotrophic nitrification, and microbial groups in acid forest soils of subtropical China. Biol Fert Soil 49(3):323-331

\section{Submit your manuscript to a SpringerOpen ${ }^{\circ}$ journal and benefit from:}

- Convenient online submission

- Rigorous peer review

- Open access: articles freely available online

High visibility within the field

- Retaining the copyright to your article

Submit your next manuscript at $\boldsymbol{\nabla}$ springeropen.com 